\title{
Summary of macrofloral biostratigraphy of Sydney Coalfield, Nova Scotia, Canada (Carboniferous, Westphalian/Cantabrian age)
}

\author{
Erwin L. Zodrow \\ Department of Geology, University College of Cape Breton \\ Sydney, Nova Scotia B1P 6L2, Canada
}

Date Received May 25, 1988

Date Accepted June 23, 1989

\begin{abstract}
Bell's (1938) macrofloral biostratigraphy (three floristic zones of Westphalian C and D ages) of the Sydney Coalfield is fundamentally revised. The revision is based mainly on two lines of evidence: (1) newly collected macrofloras (sphenophylls, odontopterids, pecopterids) by the present author and K. McCandlish since 1974 from the upper part of the Sydney Coalfield in the Point Aconi area, and (2) extension of ranges for some of Bell's records, especially S. cuneifolium and Linopteris obliqua. As interpretative results, the age of the Sydney Coalfield is considered to be Westphalian C to Cantabrian (earliest Stephanian), with the two recognized macrofloristic zones (Lonchopteris eschweileriana and L. obliqua zones) of Westphalian C, and Westphalian D and Cantabrian ages, respectively. Key words: macrofloral biostratigraphy revision, Westphalian C-Cantabrian, Sydney Coalfield, Canada.
\end{abstract}

\begin{abstract}
La biostratigraphie macrofloristique du Bassin houiller de Sydney, telle qu'établie par Bell en 1938 (trois zones floristiques d'âges westphaliens $C$ et D), fait l'objet d'une profonde révision qui se justifie surtout (1) par de nouvelles récoltes de macroflore (sphénophyllées, odontoptéridées, pécoptéridées) réalisées depuis 1974 par l'auteur et K. McCandlish dans la partie supérieure de ce bassin (région de Point Aconi), ainsi que (2) par l'élargissement de l'extension d'une portion des taxons recensés par Bell, notamment $S$. cuneifolium et Linopteris obliqua. Suite à cette interprétation, on considère que l'âge du Bassin houiller de Sydney s'échelonne du Westphalien B au Cantabrien (début du Stéphanien). De plus, on y reconnaît deux zones macrofloristiques, soit la Zone à Lonchopteris eschweileriana et la Zone à $L$. obliqua, respectivement d'âges westphalien $C$ et westphalien $\mathrm{D}$ à cantabrien. Mots-clés: biostratigraphie mactofloristique, révision, Westphalien C à Cantabrien, Bassin houiller de Sydney, Canada.
\end{abstract}

[Traduit par le joumal]

\section{INTRODUCTION}

In late Carboniferous (Silesian) time, Cape Breton Island, Nova Scotia, occupied a southern plate position on Laurasia between ancestral NW Europe, Spain and eastern North America (Fig. 1). During this time the area of coal deposition that occupied much of NW Europe and NE Spain extended westerly into eastem Canada, i.e., Newfoundland, Nova Scotia, New Brunswick, and the Gulf of St. Lawrence. Huge coal deposits (Hacquebard, 1986) were consequently laid down, particularly in the flood-plain palaeoenvironment of the Sydney Coalfield of Cape Breton Island (Hacquebard and Donaldson, 1969).

The careful stratigraphic work in the Sydney Coalfield by Robb (1876) was improved by Bell (1938) who additionally established reliable coal lithostratigraphy. Furthermore, results of studies by Gibling et al. (1987, and references therein) indicate that no significant hiatuses are present within the succession, and evidence presented (Bell, 1938; Gibling et al., 1987) showed that the coalfield is tectonically little deformed. These results, combined with macrofloral data of Bell (1938) and additional collections by the author, mean that a high degree of confidence can be attached to reported macrofloral ranges in the Sydney Coalfield in that they are (1) lithostratigraphically accurately coordinated and controlled, and (2) interpreted correctly in their relative order of occurrence and disappearance. Hence, the statement that, of the Canadian Carboniferous, the best described macrofloras and most detailed evidence for their vertical distribution are available from Sydney Coalfield, is defensible.

The present report summarizes the current state of the macrofloral biostratigraphy for the Sydney Coalfield, with ramifications for a modernization of Maritime Carboniferous biostratigraphy.

\section{PREVIOUS WORK ON BIOSTRATIGRAPHY}

Bell (1938) established three floristic zones to which he assigned Westphalian $C$ and $D$ ages (Fig. 2), after comparisons with macrofloral floral ranges of the Staffordian and the Radstockian of Great Britain and also with those of the Appalachian section. He suspected correctly (Bell, 1938, p. 18) that the Point Aconi rocks are homotaxially Stephanian. His only evidence was Sphenophyllum oblongifolium (Germar et Kaulfuss) which he 


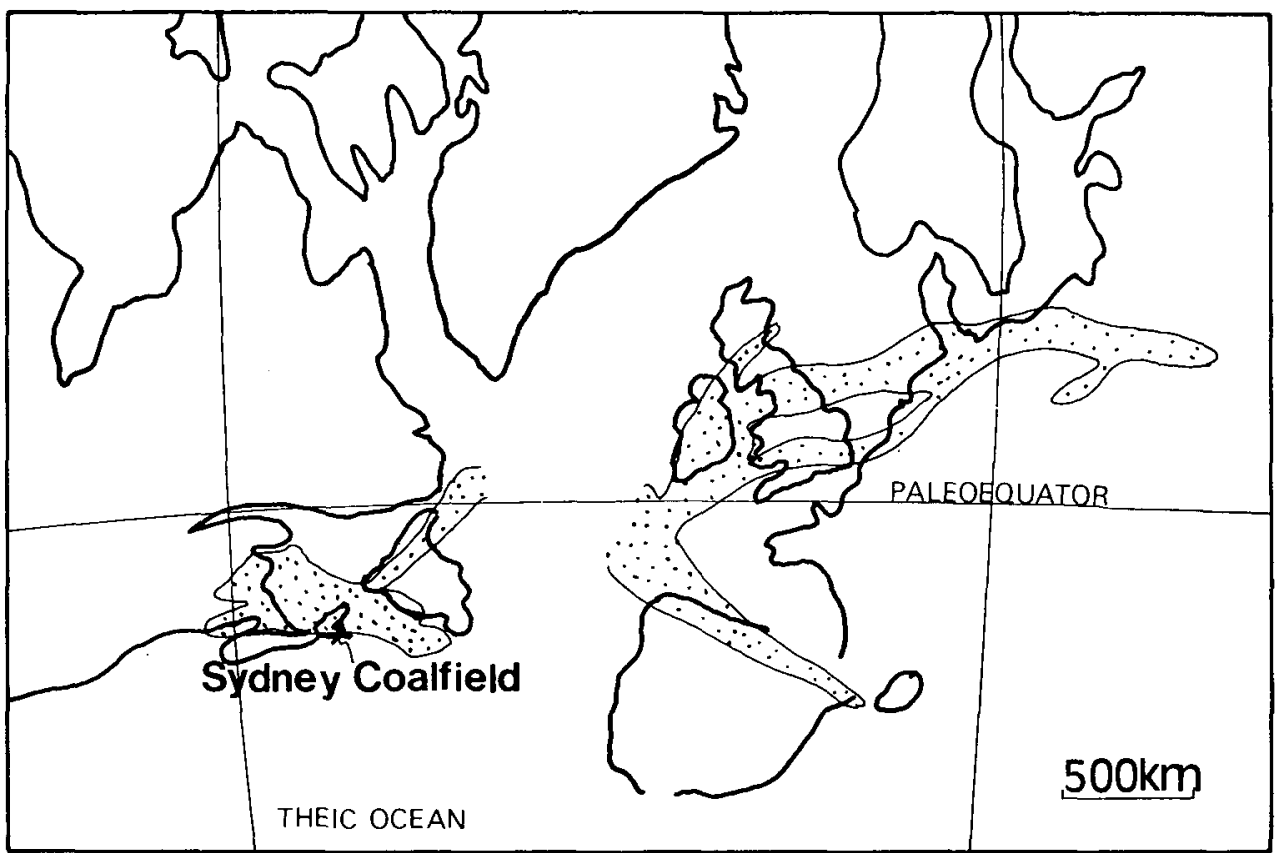

Fig. 1. Palinspatic map showing relative positions of parts of Europe and NE America during Westphalian D time (Zodrow and Cleal, 1985, Fig. 1). Stippled areas represent sedimentary deposition.

failed to illustrate convincingly (Laveine, 1977,p. 76). Moore et al. (1944) attempted to correlate the Sydney Coalfield with North American Pennsylvanian strata, and Laveine (1977) with strata of the Nord-Pas-de-Calais and the Lorraine coalfields of France, using palynologic data by Barss (1967) as well.

\section{CONSIDERATION OF SELECTED TAXA}

Figure 2 provides a range chart of important biostratigraphic plant species of which only those which require annotation are reiterated below. Criteria of importance include (1) a good understanding of the plant concept, including circumscription of variation for consistent and unambiguous global identification, (2) unbiased taxonomy, (3) synonymy, (4) known range in Sydney, and (5) wide geographic distribution outside the Sydney Coalfield.

\section{Fronds of Seed Ferns}

Lonchopteris eschweileriana Andrae is found only at the Shoemaker Seam. This is North America's only known occurrence. In Europe it is a well-recognized Westphalian C floral element.

Odontopteris cantabrica Wagner is found only at the Lloyd Cove Seam. See Zodrow (1985) for identity arguments with $O$. cantabrica and $O$. schlotheimii (Brongniart). The species, a rare Stephanian element, is reported from England, the Saarland, the Caucasus, and its type location, northwestern Spain. All Sydney specimens figured as odontopterid, with the exception of those in Zodrow (1985, p. 107), are misidentified. The Sydney odontopterid biostratigraphy, involving the ranges of only two species, is simple (Fig. 2).
Linopteris obliqua (Bunbury) is the index fossil for the floral zone recognized throughout Sydney Coalfield above the Tracy Seam (Fig. 2). For diagnosis and morphometrics see Zodrow and McCandlish (1978), and for comparison with Reticulopteris munsteri (Eichwald) see Zodrow and Vasey (1986). In western continental Europe the species is surrounded with taxonomic controversy, but it occurs in northwestern Spain, Great Britain (where it is an index to basal Westphalian D), in Upper Silesia (Poland), and probably northwestern China.

Neuropteris ovata Hoffmann was recognized by Zodrow and Cleal (1988) as being a chronospecies. N. ovata var. simonii (Bertrand) is representative of the lower Westphalian $\mathrm{D}$, and $N$. ovata var. sarana (Bertrand) and $N$. ovata var. aconiensis $\mathrm{n}$. var. Cleal et Zodrow of the upper Westphalian D. N. ovata sensu lato is very wide-spread and occurs also in the Cathaysian flora of China.

\section{Fronds of Pecopterids}

Pecopteriscf. lamuriana Heer has not been previously described from Sydney. It is one of the smallest-leafed pecopterids: frond large, quadripinnate; racheis of all orders very thick and prominently punctate (Fig. 3); penultimate pinnae lanceolate, slender in outline, contracted at base, tapering to a point (Fig. $3 \mathrm{~A}), 11 \mathrm{~cm}$ long, $3 \mathrm{~cm}$ wide, in terminal position ultimate pinnae become entire-margined pinnules; ultimate pinnae widely spaced from each other, short $1 \mathrm{~cm}$ long 1-2 mm wide, round tipped (Fig. 3B); pinnules round, pinnatifid, round, up to $1 \mathrm{~mm}$ long and wide, largest at base of ultimate pinna (heteromorphs), fused in terminal section; venation hidden by hairy pinnule surfaces. Its range is not completely known and therefore the species is omitted from 


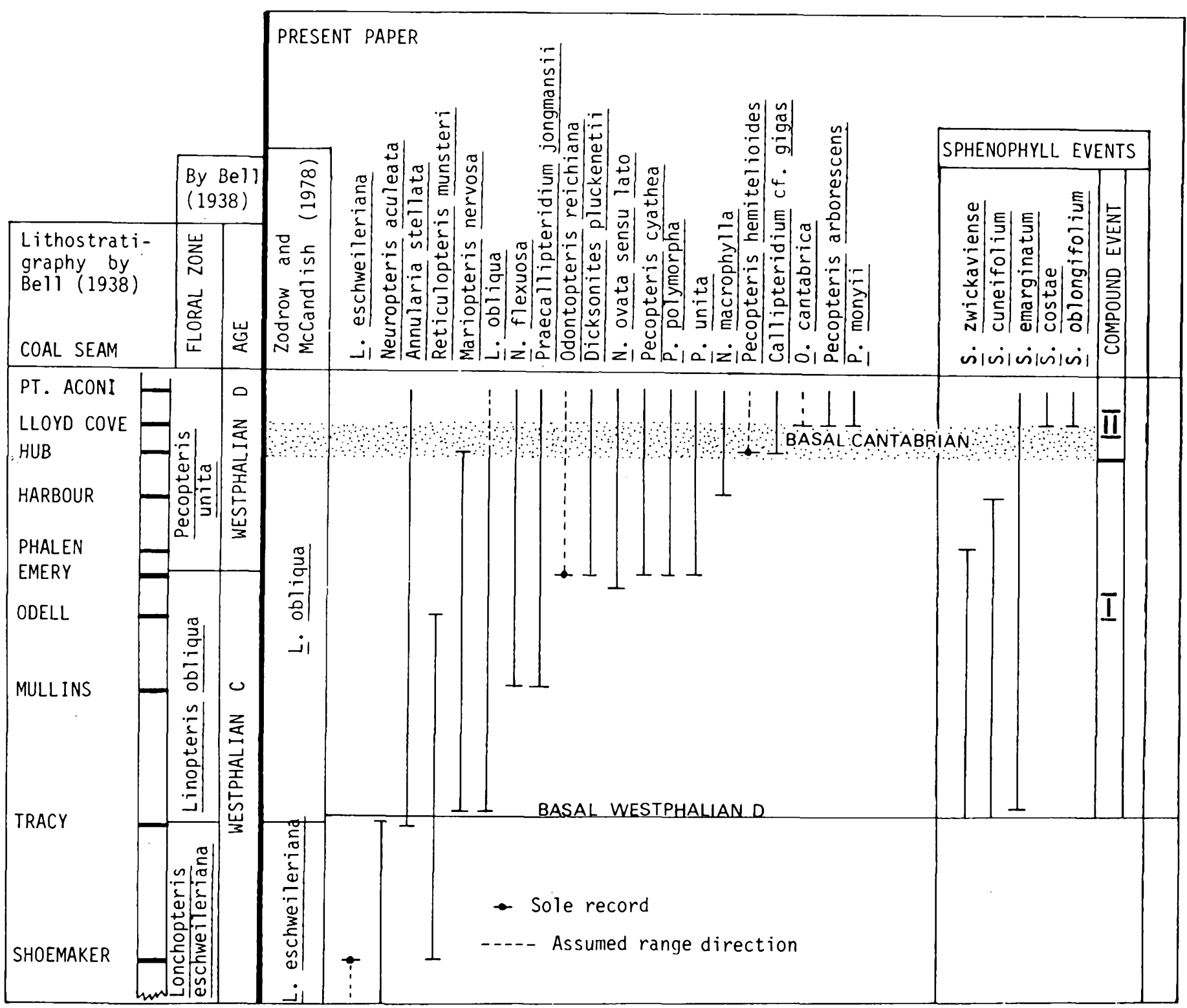

Fig. 2. Range chart of Sydney Coalfield (see text). Stippled band indicates stratigraphic uncertainty in locating basal Cantabrian. One inch is approximately 700 feet. Sphenopterids are omitted as they are being revised.

Figure 2. In Europe and China, the species is found in the upper Westphalian D to lower Stephanian.

Pecopteris monyiiZeiller has not been previously described from Sydney. Its characteristics are: frond tripinnate(?); ultimate pinnae linear-lanceolate, $6-8 \mathrm{~cm}$ long, $5-9 \mathrm{~mm}$ wide, obtusepointed; pinnules fused and emarginate, ovate, or parallel-margined up to $4-5 \mathrm{~mm}$ long; midvein decurrent dichotomizing on reaching apex; lateral veins arcuate to straight, dichotomizing in larger in proximal pinnules. This species unquestionably has its own taxonomic integrity (Zodrow, in press), but unless large specimens are available $P$. monyii and $P$. unita Brongniart are difficult to separate.

\section{Sphenophylls (vine-like climbing plants)}

Sphenophyllum costae (Sterzel) has not been previously described from Sydney. A large-leafed sphenophyll with heterodentate distal margin, i.e., both obtuse and acute teeth occur at the distal margin of one leaflet. The species is wide-spread in North America, Europe, and Asia and occurs in the highest Westphalian $D$ and basal Stephanian. It ranges into the Permian in China (Zodrow, 1989).

Sphenophyllum zwickaviense Storch has not been previously described from Sydney. A large-leafed sphenophyll with acute teeth at the distal margin, it is not as wide-spread geographically 


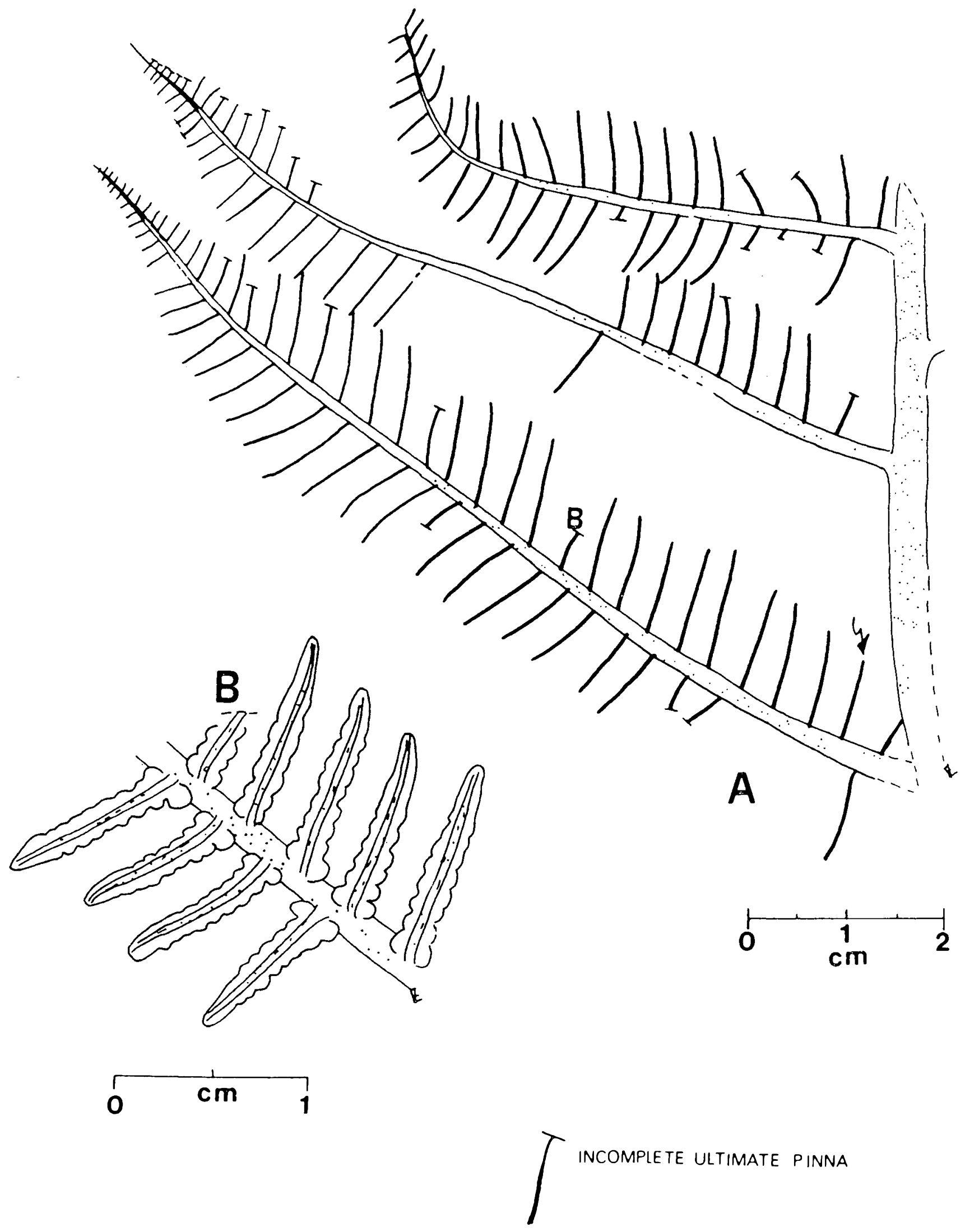

Fig. 3. Pecopteris cf. lamuriana; (A) rachial outline of entire specimen; (B) detail of the thick, punctate ultimate racheis, basal pinnule heteromorphs, and widely spaced ultimate pinnae. 
as $S$. costae, and is typically a Westphalian D element (Zodrow, 1989).

Only five sphenophyll species have been recognized in the Sydney Coalfield (Fig. 2; based on Zodrow, 1989). Defined on the basis of large or small leaflets, or acute or obtuse tooth forms, those of the Canadian Carboniferous compare fully with their European counterparts. If the argument of heterogeneity is used to unite allied species kept separate in Europe, as S. saxonicumsaarensis-orbicularis-zwickaviense, or $S$. costae-longifoliumalatifolium-geinitzii complexes are, a residual of over 50 documented species found in the European Namurian-WestphalianStephanian (Storch, 1984), but not found here, remains to be explained. The small number of sphenophyll species in the Sydney Coalfield is puzzling in view of the existence of a landbridge between ancestral Cape Breton Island and Europe. Stress factors of evolution advocated by DiMichele et al. (1987) and Vasey (1984) may be relevant in retarding sphenophyll diversification in the paralic Sydney Basin. Alternatively, the small number of species could be due to taxonomic oversplitting of European sphenophylls, based in part on underestimating individual variation or on insufficient knowledge of polyphylly. S. emarginatum (Brongniart) is such an example in Canada. It is frequently misidentified, as indicated in the synonomy list (Zodrow, 1989), and the misidentifications reflect the heterophylly, anisophylly, and in general the heterogeneity of the species which are so difficult to recognize in fragmentary material.

\section{Alethopterids}

At or near the Mullins Seam stratigraphically important fossils appeared and were recorded by Bell (1938) as Alethopteris friedelii Bertrand, and $A$. valida Boulay. His $A$. valida specimens are now in part recognized (Laveine, 1977) as representing Praecallipteridium jongmansii (Bertrand) which is a callipterid. Sydney's alethopterids, however, require revision before biostratigraphic use can be made of them.

\section{DISCUSSION}

Bell's (1938, Fig. 1) criteria for biostratigraphic zonation were based mainly on first occurrence of taxa and on the use of guide fossils, particularly Linopteris obliqua. Bell separated his two upper Zones, in part, on the premise that the apparent range of $L$.obliqua terminated at the Emery Seam, where Ptychocarpus unitus (see Fig. 2) entered the record (i.e., the ranges of $L$. obliqua and $P$. unitus are mutually exclusive, according to Bell). Zodrow and McCandlish (1978) showed that these two species were contemporaries in Bell's $P$. unita Zone, and, that some of the other zonal plants recognized by Bell only below the Emery seam range above this seam. Hence, age and zonal emendations are required.

\section{The Base of Westphalian D}

At the Paris Carboniferous Conference in 1963, the decision was made to link the Westphalian C/D boundary with the oldest occurrence of Neuropteris ovata Hoffmann sensu lato. Subsequently, Laveine (1977) argued for indexing this boundary in the context of other floral changes that took place about that time just below the base of the $N$. ovata Biozone. To this effect he proposed a model of a succession of palaeobotanic events, culminating with the $N$. ovata occurrence as the event which indexes the boundary. Comparing the Sydney data with that of Laveine's model, a general homotaxial agreement is evident (Zodrow and Cleal, 1985). Despite the fact that $N$. ovata entered the geologic record $1000 \mathrm{~m}$ higher at the Emery Seam, Zodrow and Cleal (1985) argued for relocating the C/D boundary from Bell's (1938) placement at the Emery Seam to just above the lower-situated Tracy Seam (Fig. 2). The mid-Westphalian D upper floral change recognized by Zodrow (1986, Fig. 13) at the level of the Emery is consistent with the relocation. Moreover, the mid-Westphalian D lower floral change that took place during Mullins-Seam time (Zodrow, 1986, Fig. 13) is inconsistent with Laveine's (1977) relocation of the C/D boundary from the Emery Seam to the Mullins Seam. In conclusion, the arguments favor the position that basal Westphalian D is at or near the level of the Tracy Seam. Hence, the Lonchopteris eschweileriana Zone is confined to the Westphalian C and encompasses the strata between the erosional base of Sydney Coalfield and the top of the Tracy Seam, in agreement with Bell (Fig. 2).

\section{Base of the Cantabrian (= basal Stephanian)}

There are two principal problems with the acknowledged existence of the Cantabrian time interval. Firstly, given a sparse flora Cantabrian strata are indistinguishable from the classic French Stephanian A flora. Secondly, no single reliable indicator exists for the base of the Cantabrian type section in NW Spain (Zodrow and Cleal, 1985, pp. 1469-1471). It is therefore essential to be able to demonstrate that, in the same way as the base of the Westphalian D can be identified by paleofloral events, successive changes in floristic composition occurred at the base of the Cantabrian. Although the changes were not formulated by Wagner (Wagner, 1984; Wagner in Wagner et al., 1983, p. 125), on the basis of his biostratigraphic data, a succession of mostly compound paleobotanical events is evident up to and beyond the base of the Odontopteris cantabrica Biozone. The succession can be arranged as follows:

(1) bottom range of Alethopteris grandinioides var. subzeilleri Wagner,

(2) bottom ranges of Lobatopteris viannae (Teixeira) and Pecopteris monyii,

(3) top range of Mariopteris nervosa (Zeiller),

(4) bottom range of Alethopteris bohemica Franke, and Pseudomariopteris corsinii (Teixeira),

(5) bottom ranges of Odontopteris brardii Brongniart, A. barruelensis Wagner, A. zeilleri Ragot, L. lamuriana (Heer), P. melendezii Wagner, $S$. oblongifolium, and $O$. cantabrica, and

(6) bottom ranges of Callipteridium striatum Wagner and $A$. leonensis Wagner.

It is clear from a critical analysis done by Zodrow and Cleal (1985), considering in their arguments diachroneity of the above 
events, nomenclatural divergence, endemic taxa, biased taxonomy, and synonymy, that the recognition of the basal Cantabrian outside of NW Spain would have to rely mainly on events 3,5 and 6 above. Moreover, the analysis showed clearly that $O$. cantabrica is as yet the only floral element to indicate the presence of the $O$. cantabrica Biozone outside of Spain.

In Sydney Coalfield the situation is that out of the 7 individual events comprising the Spanish compound event 5, we have two representatives entering the record at or above the Lloyd Cove Seam: O. cantabrica and S. oblongifolium, and out of the two in Spanish compound event 6 we have only one representative at the generic level of Callipteridium (Zodrow and Cleal, 1985), of which $C$. gigas (Gutbier) enters the record below the Lloyd Cove at the Hub Seam (Fig. 2). In conclusion, it can be reasonably inferred that Cantabrian strata are present in the Sydney Coalfield (Zodrow and Cleal, 1985, Fig. 4).

The accurate positioning of the Westphalian/Stephanian, or basal Cantabrian boundary, in the Sydney Coalfield is, however, a different and more difficult matter. Additional homotaxial evidence of palaeobotanic events commonly occurring at or near basal Stephanian outside of Sydney are required. Available for testing from Sydney are the sphenophylls and the cyathocarpuids (members of Pecopteris arborescens Group sensu Corsin: $P$. arborescens (Schlotheim), P. cyathea (Schlotheim) non Brongniart, $P$. hemitelioides Brongniart, and $P$. paleacea Zeiller.

Within the framework of sphenophyll biostratigraphy, the situation in the Sydney Coalfield is that S. cuneifolium (Stemberg) and $S$. zwickaviense more or less reach a common top range in the presence of $S$. emarginatum, which ranges into the youngest strata at Point Aconi. This represents compound paleobotanical 'event I' (inset, Fig. 2). An additional 'event II' comprises the common first occurrences of $S$. oblongifolium and $S$. costae at the Lloyd Cove Seam, subsequent to 'event I'. Comparison with corresponding continental European sphenophyll events, summarized most recently by Storch (1984), and with those of northwest Spain (Wagner, 1983), shows homotaxial agreement. Furthermore, it is noted that Stephanian elements $P$. arborescens, and $P$. hemitelioides enter the record at or above the Lloyd Cove Seam. As a first approximation, it is proposed to put the Westphalian D/Cantabrian boundary at the level of the Lloyd Cove Seam to coincide with the first record of $O$. cantabrica. The boundary could, however, be as low as the Hub Seam. This is shown by stippling in Figure 2. Strata from the Tracy Seam upwards to the top of the coalfield are identified with the Linopteris obliqua Zone (Fig. 2).

It is obvious from the foregoing summary that relative to extracted data points 1 to 6 above by Wagner $(1984$, p. 125; 1983), other events would have to be considered for providing a means to test for the base of the Cantabrian. Such a replacement model for homotaxis is proposed in Figure 4, in which the first occurrence of $O$. cantabrica marks the basal Cantabrian.

\section{BIOSTRATGRAPHIC CONCLUSIONS}

Significant palaeobotanic events occurred at the Lloyd Cove and the Tracy Seams (Fig. 2). In biostratigraphic terms

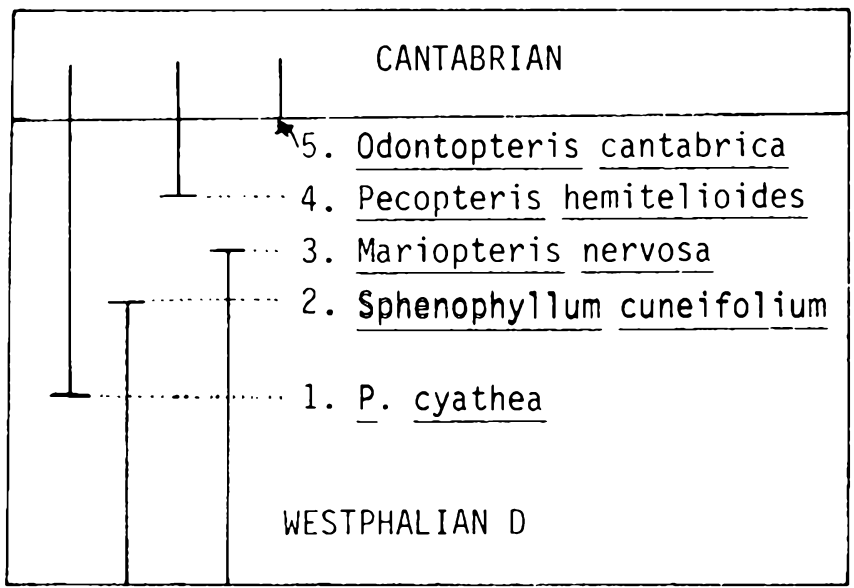

Fig. 4. Proposed model for indexing basal Cantabrian using a succession of five taxa.

these events are interpreted to index the Westphalian D/Cantabrian (basal Stephanian), and the Westphalian C/D boundaries, respectively. The two recognized floristic zones, corresponding to Westphalian D and the Cantabrian, and the Westphalian C, respectively, are the Linopteris obliqua and the Lonchopteris eschweileriana Zones.

These events are homotaxial with the Carboniferous (west to east) of northwest Spain, south Wales, and Europe, i.e., the Euroamerican Floral Realm (Zodrow, 1985, 1986, 1989, in press; Zodrow and Cleal, 1985).

\section{ACKNOWLEDGEMENTS}

I am grateful to N.S.E.R.C. for a three-year operating grant which made this paper possible and to reviewers of an earlier version of it for constructive and very pointed criticism.

BARSS, M.S. 1967. Illustrations of Canadian fossils: Carboniferous and Permian spores of Canada. Geological Survey of Canada. Paper 67-11, $94 \mathrm{p}$.

BELL, W.A. 1938. Fossil flora of Sydney Coalfield, Nova Scotia. Geological Survey of Canada, Memoir 215, pp. 1-334.

DIMICHELE, W.A., PHILLIPS, T.L., and OLMSTEAD, R.G. 1987. Opportunistic evolution: Abiotic environmental stress and the fossil record of plants. Review of Palaeobotany and Palynology, 50, pp. 151-178.

GIBLING, M.R., BOHNER, R.C., and RUST, B.R. 1987. The Sydney basin of Atlantic Canada: An upper Paleozoic strike-slip basin in a collisional setting. In Sedimentary Basins and Basin-forming Mechanisms. Edited by C. Beaumont and A.J. Tankard. CSPG Memoir 12, AGS Special Publication 5, pp. 269-285.

HACQUEBARD, P.A. 1986. The Gulf of St. Lawrence Carboniferous Basin; the largest coalfield of eastern Canada. CIM Bulletin, 79, pp. 67-78.

HACQUEBARD, P.A. and DONALDSON, J.R. 1969. Carboniferous coal deposition associated with flood-plain and limnic environments in Nova Scotia. In Environments of Coal Deposition. Edited by E.C. Dapples and M.E. Hopkins. Geological Society of America, Special Paper, pp. 143-191.

LAVEINE, J.-P. 1977. Report on the Westphalian D. In Symposium on Carboniferous Stratigraphy. Edited by V.M. Holub and R.H. Wagner. Prague, 1973, pp. 71-87. 
MOORE, R.C. et al. (editors). 1944. Correlation of Pennsylvanian formations of North America. Bulletin of the Geological Society of America, 55, pp. 657-706.

ROBB, C. 1876. Report on explorations and surveys in Cape Breton, Nova Scotia. Canadian Geological Survey, Report of Progress, pp. 166-266.

STORCH, D. 1984. Die stratigraphische Verbreitung der europäischen Sphenophyllum-Arten. In Neuvième Congrès International de Stratigraphie et de Géologie du Carbonifère. Edited by P.K. Sutherland and W.L. Manger. Washington and Champaign-Urbana, Compte Rendu, 2, pp. 523-532.

VASEY, G.M. 1984. Westphalian macrofaunas in Nova Scotia: Paleoecology and correlation. Unpublished Ph.D. thesis, University of Strathclyde, Glasgow, $467 \mathrm{p}$.

WAGNER, R.H. 1983. Late Westphalian D and early Cantabrian floras of the Guardo Coalfield. In Geology and Palaeontology of the Guardo Coalfield (NE León - NW Palencia), Cantabrian MTS. Edited by R.H. Wagner, L.G. Femández Garcia, and R.M.C. Eagar. Instituto Geológico y Minero de España, Madrid, pp. 57-91, plus Pls. 1-48.

. 1984. Megafloral zones of the Carboniferous. Neuvième Congrès de Stratigraphie et de Géologie du Carbonifere, Washington-Urbana, 1979, Compte Rendu, 2, pp. 109-134.
ZODROW, E.L. 1985. Odontopteris in the Upper Carboniferous of Canada. Palaeontographica, Abt. B, 196, pp. 79-110.

. 1986. Succession of paleobotanical events: Evidence for midWestphalian D floral changes, Morien Group (Late Pennsylvanian, Nova Scotia). Review of Palaeobotany and Palynology, 47, pp. 293-326.

. 1989. Revision of Silesian sphenophyll biostratigraphy of Canada. Review of Palaeobotany and Palynology, 58, pp. 301-331.

. In press. Revision of the cyatheoid Group (marattiaceous tree ferns, Permo-Carboniferous). Palaeontographica, Abt. B.

ZODROW, E.L. and CLEAL, J.C. 1985. Phyto- and chronostratigraphical correlations between the late Pennsylvanian Morien Group (Sydney, Nova Scotia) and the Silesian Pennant Measures (south Wales). Canadian Journal of Earth Sciences, 22, pp. 1465-1473.

ZODROW, E.L. and CLEAL, C.J. 1988. The structure of the Carboniferous pteridosperm frond Neuropteris ovata Hoffmann. Palaeontographica, Abt. B, 208, pp. 105-124.

ZODROW, E.L. and MCCANDLISH, K. 1978. Distribution of Linopteris obliqua in the Sydney Coalfield of Cape Breton, Nova Scotia. Palaeontographica, Abt. B, 168, pp. 1-16.

ZODROW, E.L. and VASEY, G.M. 1986. Mabou Mines section: Biostratigraphy and correlation (Pennsylvanian Pictou Group, Nova Scotia, Canada). Journal of Paleontology, 60, pp. 208-232. 